\title{
Using of GIS Software for Mapping the Climatic Data Obtained from Internet Network: Iraq Case Study
}

\author{
Sabah Hussein Ali \\ Remote Sensing Center \\ University of Mosul
}

(Received 5/6/2018 , Accepted 8/10/2018)

\begin{abstract}
Nowadays, the long-term climatic data supplied by the famous internet sites, plays an important role in analyzing and mapping of various climatic features (temperature, precipitation, solar radiation ... etc.). Precipitation is one of the important elements in agriculture. It is a major field in climatological studies. Studying precipitation is important to identify precipitation characteristics; temporal and spatial variability.

In the present study, extract for each $\left(0.5^{*} 0.5\right)$ degree grid cell of the monthly precipitation data for the year 2016 except the summer months (June - July - August) using the GPCC Visualizer website is applied for Iraq country. Kriging interpolation method within the environment of ArcGIS10.3 program, the average monthly and seasonal precipitation maps are drawn. The study revealed the possibility to use the more popular website sources of historical climate datasets to compensate the lack of climate data available from the meteorological stations in Iraq, which is often difficult to obtain recent data.
\end{abstract}

Keywords: Precipitation, GIS, Kriging interpolation, GPCC, Iraq.

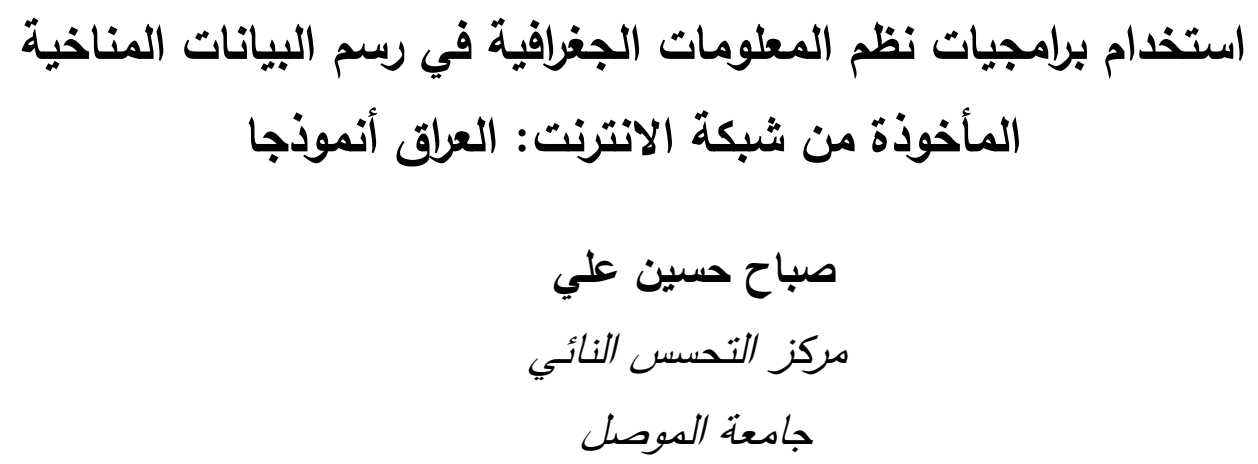


أصبحت البيانات المناخية طويلة الأجل والتي تعرض من قبل المواقع المناخية المعروفة عن طريق الانترنت، تلعب دورا هاما في تحليل ورسم الخرائط للعناصر المناخية الدهمة (درجات الحرارة، التساقط المطري،

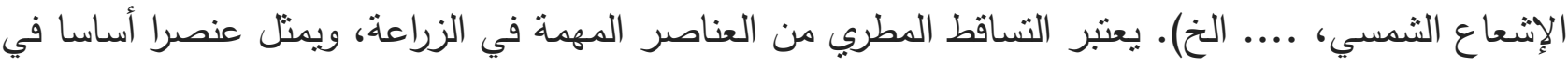
الكثثر من الدراسات المناخية، حيث ان دراسة التساقط المطري مهم في تحديد الخصائص المناخية من حيث التباين الزماني والمكاني.

في الدراسة الحالية، نم استخلاص الثبكة المكانية بدقة (0.5*0.5 درجة) لبيانات التساقط المطري الثهري للعام 2016 باستثناء أنثهر فصل الصيف (حزيران -تموز -اب) من موقع (GPCC Visualizer) للعراق كمنطقة دراسة. تم تطبيق طريقة الاستكمال المكاني (Kriging) ضمن بيئة برنامج (ArcGIS10.3) في إنثاء خرائط المعدل الثهري للتساقط المطري بالإضافة الى الخرائط الموسمية. كثنف دراسة إمكانية استخدام مواقع المناخ من الانترنت للحصول على البيانات المناخية للتعويض عن النقص في البيانات المنتفرة من محطات الأرصاد الجوية في العراق، والتي غالبا ما يصعب الحصول على معلومات التيات حديثة عنها. الكلمات الدالة: التساقط المطري، نظم المعلومات الجغرافية، استكمال Kriging، موقع GPCC، العراق

\section{INTRODUCTION}

The weather plays a critical role in eco-environmental and agricultural systems all over the world. Limited availability of meteorological records often constrains the applications of simulation models and related decision support tools. The demand for spatial data sets of weather and climatic information elements in digital form has become very important for the international organizations that interest in the global climatic change. This demand has been supported by the progressing of computer technology enabling a variety of agricultural, hydrological, ecological, geological and natural resource models and expert systems to be linked to geographic information systems (GIS) (Daly et al., 2000 ). Most of these data include quality controlled daily, monthly, seasonally, and yearly measurements of temperature, precipitation, wind, and degree-days as well as radar data and 30-year Climate Normal's (http://www.ncdc.noaa.gov/cdo-web) (http://lib.stanford.edu). The ability to better determination of the weather conditions at specific locations by the geographical coordinates and their impact on the populations, environment and infrastructures in those areas have improved dramatically through the efforts of the climatic websites. These websites are considered as an important source of climate data, which is difficult to obtain from the meteorological stations distributed for example in Iraq, which required exorbitant amount to get it. These sites also often 
adopted by the international centers, for example, the International Center for Agriculture preservatives in dry areas (ICARAD) in mapping a various climatic elements, as well as a main material in the design of a lot of scenarios for suitability agricultural through a special climatic software (De Pauw, 2008). The free download of the climatic data from these websites gives an opportunity to evaluate weather data in significant ways that could help researchers to predict the future climate conditions. In addition, can provide the quantitatively data with high temporal or spatial resolution. In addition, mapping of longer-term dataset of precipitation allows an appraisal of how the average climate is actually changing.

In this paper, we will give an outline of the integration between a long-term precipitation data from a well-known climatic website and the GIS application tools that used for modeling and mapping the spatial climatic dataset of precipitation in Iraq at 2016. The researcher depends on climate data from internationally accredited Web site (GPCC VISUALIZER). These datasets can compensate the lack of climate data available from the meteorological stations in Iraq, which is often difficult to obtain from official organizations.

\section{STUDY AREA}

The Study area is Iraq; a country located in southwestern Asia and occupying mostly the Mesopotamian Plain, located between $29^{\circ}$ and $38^{\circ} \mathrm{N}$ latitudes, $39^{\circ}$ and $49^{\circ} \mathrm{E}$ longitudes (small area lies west of $39^{\circ}$ ). Turkey borders Iraq to the north, Syria to the northwest, Kuwait and Saudi Arabia to the south, Iran to the east, and Jordan to the west as shown in (Fig. 1). Iraq is divided into four major regions: highlands in north and northeast; alluvial plain in the central and southeast sections; desert in west and southwest sections; and rolling upland between upper Euphrates and Tigris Rivers (Ali et al., 2013). The north of the country is mostly composed of mountains; the highest point being at $3600 \mathrm{~m}$ (Sissakian et al., 2016). Iraq also has a narrow section of coastline measuring $58 \mathrm{~km}$ on the northern Arabian Gulf. 


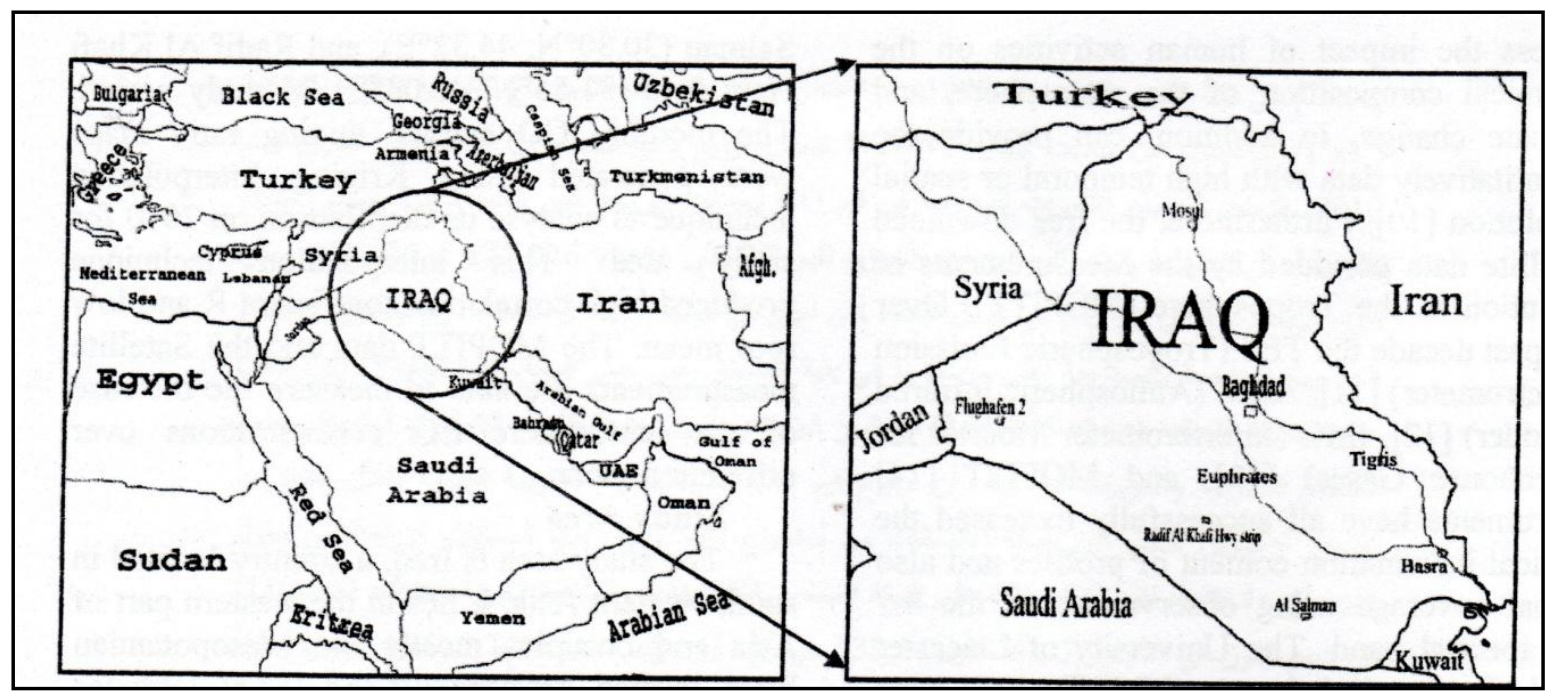

Fig. 1: The Geographical Features of the Study Area.

Most of Iraq has a hot and arid climate with subtropical influence. Typically, precipitation is low, the maximum rainfall occurs during the winter months. The northern mountainous regions have cold winter with occasional heavy snows, sometime causing extensive flooding (Rajab, 2012).

\section{WEATHER STATIONS}

Historical climate data, that is geospatially explicit, are necessary for many modeling processes, especially on a regional scale. For example, crop simulation models typically require large amounts of climatic input data, including maximum and minimum temperatures, precipitation, and solar radiation at a daily time step (Wei et al., 2012). These climatic datasets can be provided by few publically available sources including weather station data, interpolated grids based on station data, and satellite-derived data.

The methodology applied for the present study depends on the historical climatic data given by the weather stations through the internet websites. The following provides some websites of the more popular sources of historical climate datasets:

\section{A. NCDC}

One of the most well-known sources of regional weather station data come from National Climatic Data Center (NCDC) sector of the National Oceanic and Atmospheric Administration (NOAA). Daily observations of temperature, 
precipitation, winds, pressure, snow, and others can be found for over 15,000 stations worldwide (http://www7.ncdc.noaa.gov).

\section{B. FAOCLIM 2.0}

FAOClim 2.0 is a global agroclimatic database containing data from almost 32,000 stations for up to 14 observed and computed agroclimatic parameters. The database includes both long-term averages and time series for rainfall and temperatures. The database is linked to real-time daily meteorological data flow and allows users to browse and retrieve basic data. The user can select data by geographic area, time period and parameter and can export and visualize the information in map and graph form (http://www.fao.org).

\section{WorldClim}

It's a very high-resolution dataset, which has been developed at an even high resolution for the entire globe, excluding Antarctica. WorldClim contains global estimates of monthly mean, maximum, and minimum temperatures and precipitation at a 1-km resolution (http://www.worldclim.org).

\section{GPCC}

The Global Precipitation Climatology Centre (GPCC) provides global precipitation analyses for monitoring and research of the earth's climate. The centre is a German contribution to the World Climate Research Programme (WCRP) and to the Global Climate Observing System (GCOS) (https://climatedataguide. ucar.edu). The GPCC provides gridded gauge-analysis products derived from quality controlled station data. The GPCC provides estimates for that error as well as the number of gauges used on the grid.

\section{Database:}

\section{METHODOLOGY}

The historical climatic applied in the present paper have been taken from the internet website for the GPCC of the German Weather Service through the GPCC VISUALIZER (http://kunden.dwd.de). The available data from this website consist of global grids of monthly precipitation at different periods (January1901- December 2016) with resolutions $(0.50,10$, and 2.50). The GPCC VISUALIZER based on the data of more precipitation stations (up to 45,000 globally) than any other gridded precipitation data set, as well as that the dataset does not contain gaps in the record and that all station data have been thoroughly quality-controlled (Becker, 2011). 


\section{Data extraction and transformation:}

All data applied in the present study are related to monthly average precipitation for the year 2016 as a case study. The main source of the dataset is the GPCC VISUALIZER website shown in (Fig. 2). The Extract dataset of the precipitation was selected from the GPCC Land surface Full Data Monthly Product Version 2018 mode at the spatial grid resolution of $0.5^{0}$ latitude x $0.5^{0}$ longitude (approximately $55.5 \times 55.5$ $\mathrm{km}^{2}$ ) for every month and season of the year 2010. Generally, GPCC Visualizer gives the feasibility to global spatial coverage of longitude (-180 to 180 degree) and latitude (-90 to 90 degree) and the output dataset either in ASCII file or ArcView grid. The climatic maps can be created by analyzing and processing the output data analyzed using the ArcGIS desktop software to create. ArcGIS10.3 was used for the extracting and mapping of the required precipitation data, as well as the related subsequent processing.

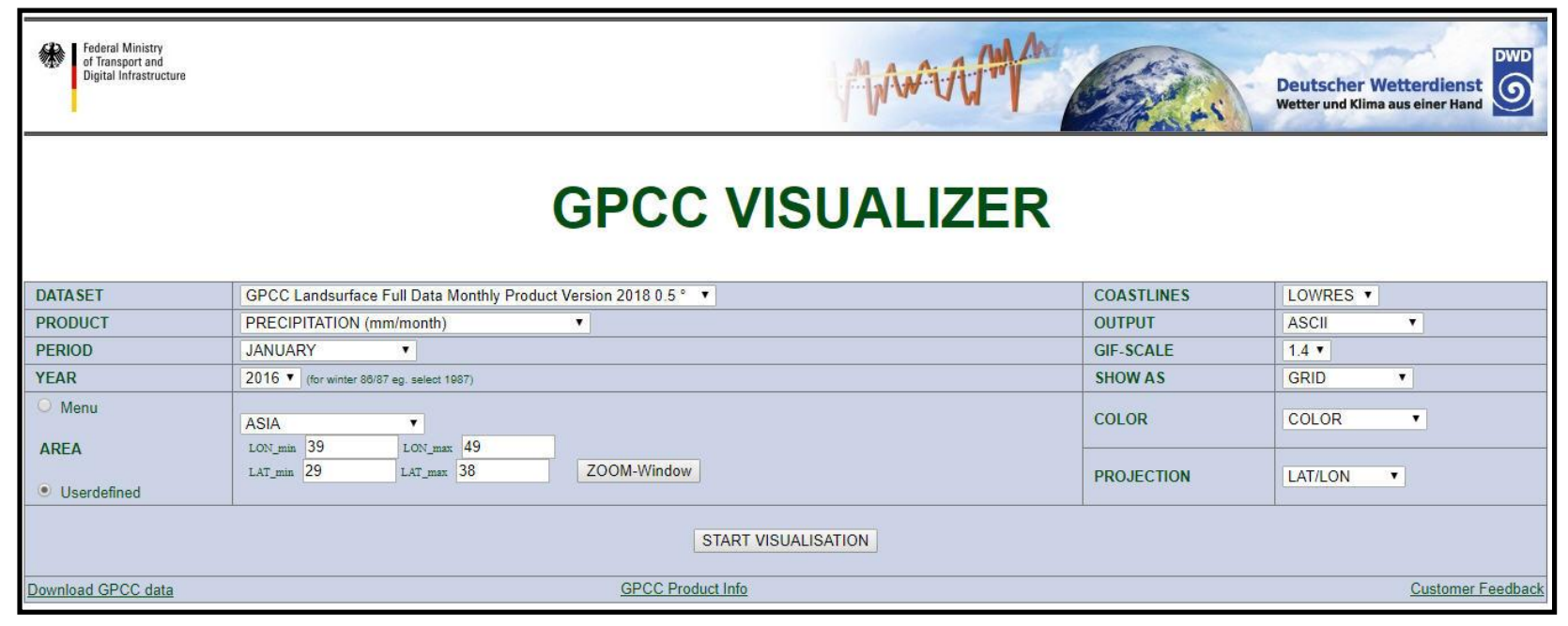

Fig. 2: GPCC VISUALIZER Screenshot.

For Iraq, the spatial coverage of the entire area is defined with the geographical coordinate system (GCS) of 29-38 N; 39-49 E. Therefore, the extraction of the precipitation data in ASCII grid format has been done within the defined geographical boundary. Then, the ASCII files are converted to Excel file with the geographical coordinates of each point.

The geodetic system of all datasets adopted in the study are defined as GCS_WGS_1984. The Excel file for each month is then added to ArcGIS9.3.1, and converted to point vector layers (shape files) for required interpolation processing. The average monthly and seasonal precipitation maps are generated using kriging algorithm technique. Generally, the interpolation is defined as the estimation of a 
variable at an unmeasured location from observed values at surrounding locations. Kriging algorithm technique is a geostatistical interpolation method that provides estimates at unsampled points based on the surrounding data collected at precise location as done in the present study. A kriged estimate is a weighted linear combination of the known sample values around the point to be estimated (Isaaks et al., 1989). In addition, a unique feature of Kriging is that it provides an estimation of the error at each interpolated point, providing a measure of confidence in the modeled surface. Therefore, the accuracy of the graduated colors in resulted precipitation maps form the downloading grid cell of $(0.5 * 0.5$ degree $)$ shown in figure (3) below will be more than those data depending on a randomly and limited number of meteorological stations as shown in (Fig. 4).

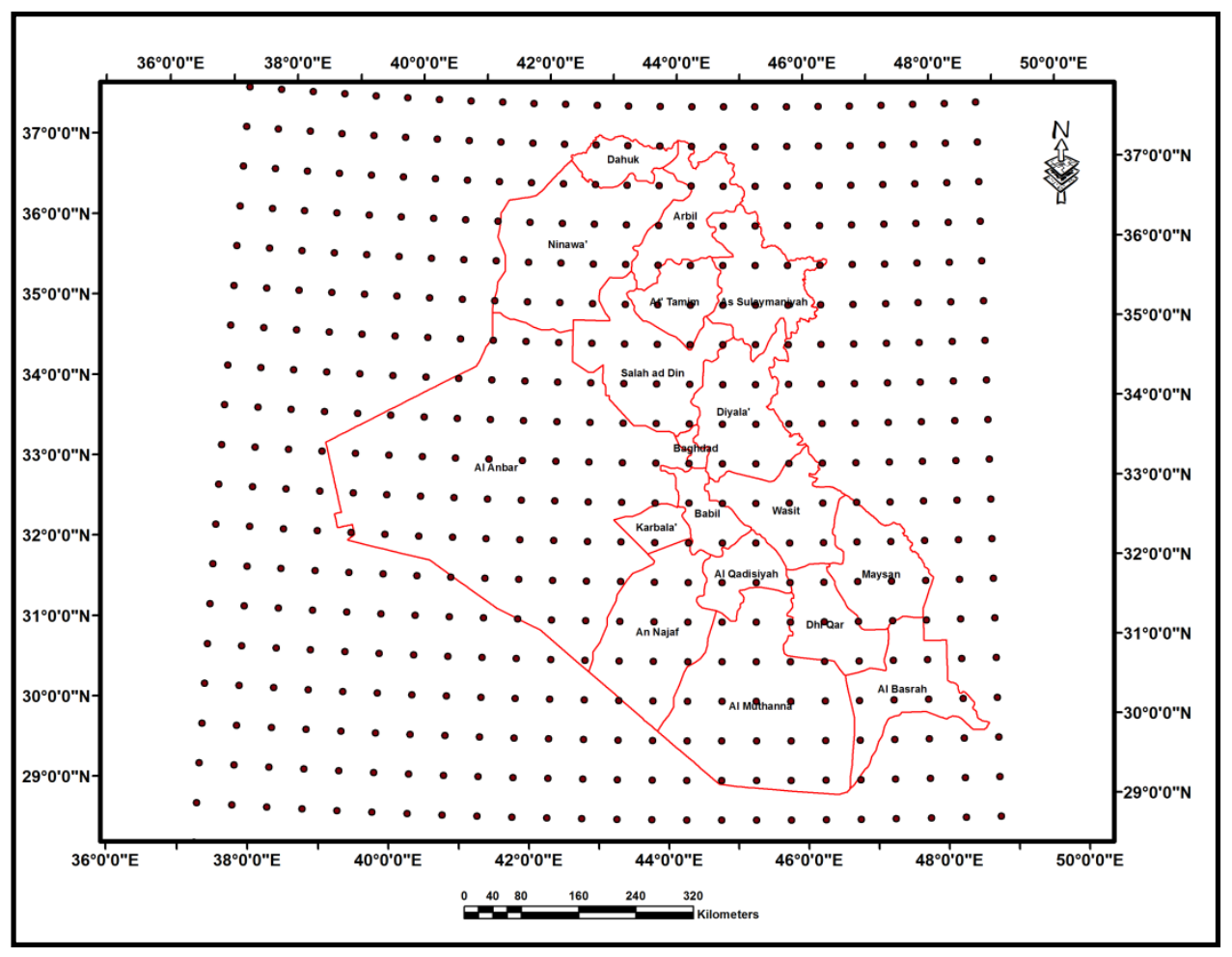

Fig. 3: The Arranged Downloading Grid Cells. 

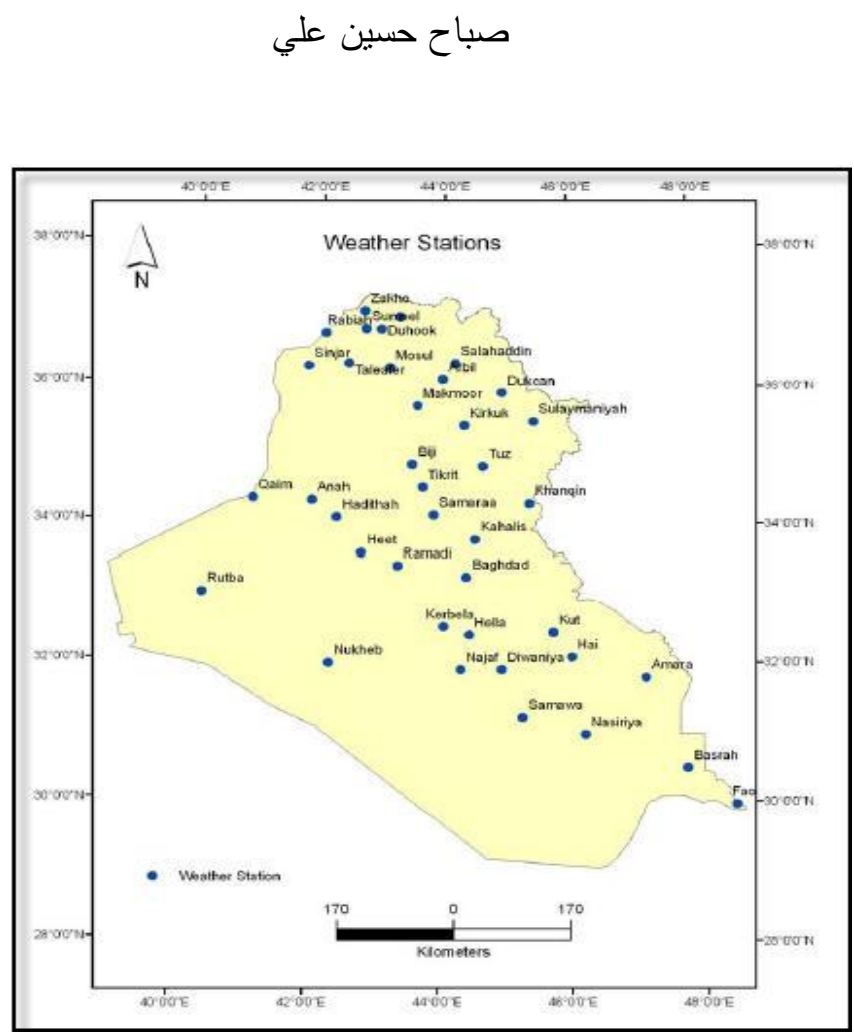

Fig. 4: The Meteorological Stations in Iraq.

\section{RESULTS AND DISCUSSION}

Nine monthly text files and three seasonal text files of the precipitation for Iraq boundary were downloaded from GPCC VISUALIZER website for one year from January to December 2016. The seasonal periods were defined as winter (Dec., Jan., Feb.: DJF), spring (March, April, May: MAM) and autumn (Sept., Oct., Nov.: SON). Table (1) gives an overview of the minimum and maximum range values of the monthly and seasonal precipitation at 2016. The spatial and temporal variations of the monthly precipitation are shown in figures (6 and 7) below. The figures show that the majority of the precipitation had been occurred from December through April, and is more abundant in the mountainous region (northern and eastern of Iraq). This result is nearly similar in the behavior of the precipitation data readout that taken from the meteorological stations distributed in Iraq and often represents one of the main climatic features as given by (Ali et al., 2013).

Precipitation and altitude variation are the two main factors influencing the climatic variations in Iraq. As it is noticed from figures (5 and 6) and table (1). The increasing of the precipitation in northern and northeastern Iraq was due to the existence the Zagros Mountains. It extends up to 3000 meters and form a natural border between the northeastern region of Iraq, western Iran and the Taurus Mountains, which form the borders between northern Iraq and southern Turkey. In the other parts of Iraq, we notice that, there is a difference in the amount of rainfall 
according to the topographical nature and on the extent of the exposure of these areas to the air depressions and air masses formed by the effects of the Mediterranean, Atlantic Ocean and the Arabian Gulf (Al-Kinani, 2014). For examples, the rainfall of the Sudanese air depression is concentrated on the southern areas and the southern parts of the central region. In the summer, there is no rainfall in Iraq due to the dominance of high tropical pressure. In addition, this season is characterized by relatively low rates of relative humidity. Therefore, we find that the summer in Iraq is hot and dry, so the rainfall data in the summer month's did not download from the website adopted in this study, while only the rainy month s dataset were downloaded and mapped.

Table 1: The Average Monthly and Seasonal Precipitation.

\begin{tabular}{|c|c|}
\hline Months and Seasons & $\begin{array}{c}\text { The min. and max. range } \\
\text { of precipitation(mm) }\end{array}$ \\
\hline January & $0.06-158.6$ \\
\hline February & $0.36-114.13$ \\
\hline March & $5.5-151.1$ \\
\hline April & $0.3-133.1$ \\
\hline May & $0-81.6$ \\
\hline September & $0-65.7$ \\
\hline October & $0.6-75.3$ \\
\hline November & $0-53.8$ \\
\hline December & $3.8-160.1$ \\
\hline Winter & $15.8-386.3$ \\
\hline Spring & $15.7-315.2$ \\
\hline Autumn & $0-117.7$ \\
\hline
\end{tabular}

The seasonal precipitation also shows that the northern and northeastern of Iraq are usually received higher amount of precipitation than the southern as illustrating in (Fig. 7). The increasing in the precipitation occurs almost in winter, autumn, spring. This result was nearly similar in the behavior of the seasonal precipitation data readout that was taken from the meteorological stations distributed in Iraq by (Al- Timimi et al., 2013). Generally, the monthly and seasonal precipitation in Iraq shows much spatial and temporal variability. Across locations and time, the amounts of precipitation that can be expected are not constant (especially in the last years) and, within bounds determined by the 'average' climate, they fluctuate randomly. 
صباح حسين علي
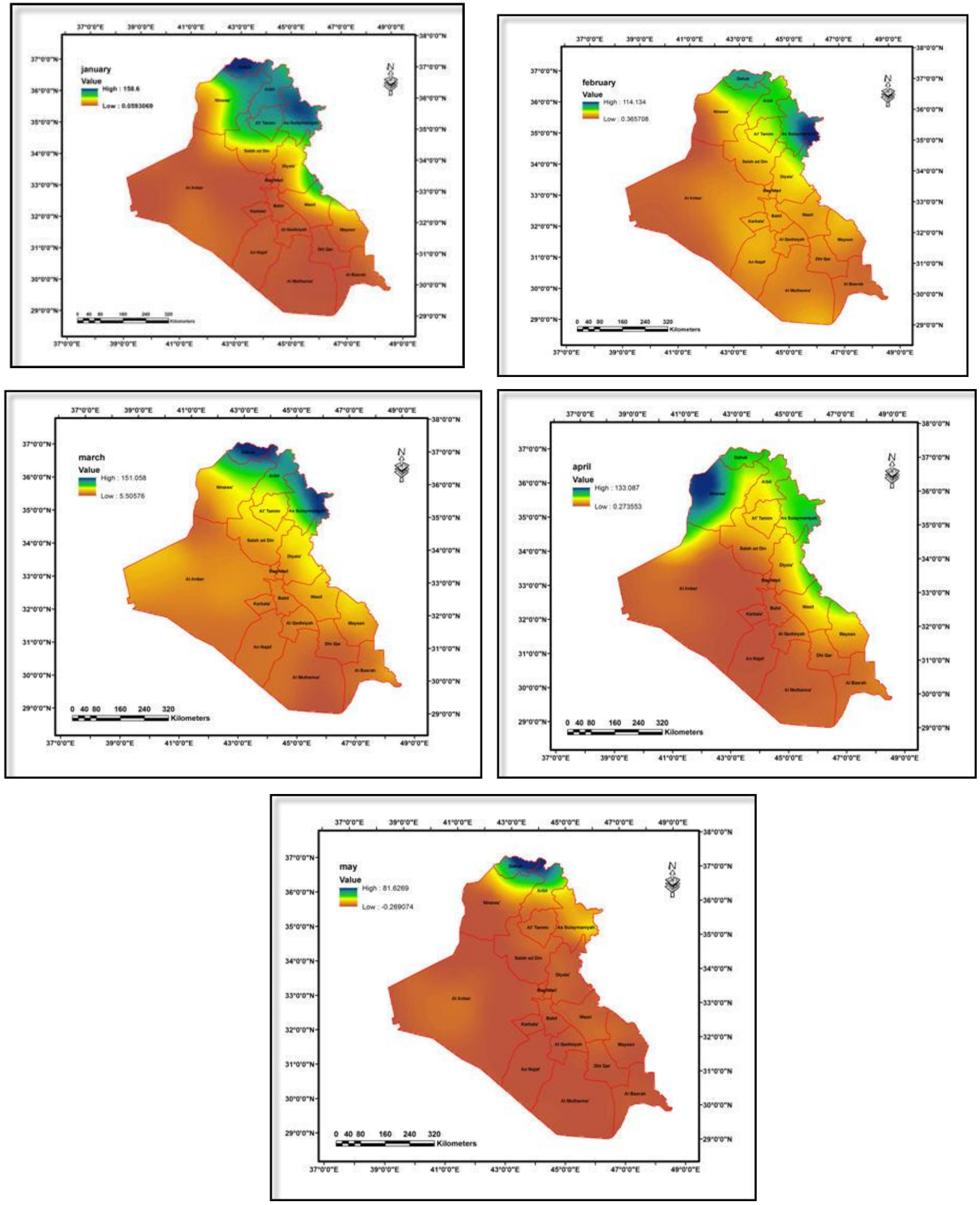

Fig. 5: Monthly Precipitation (January to May). 

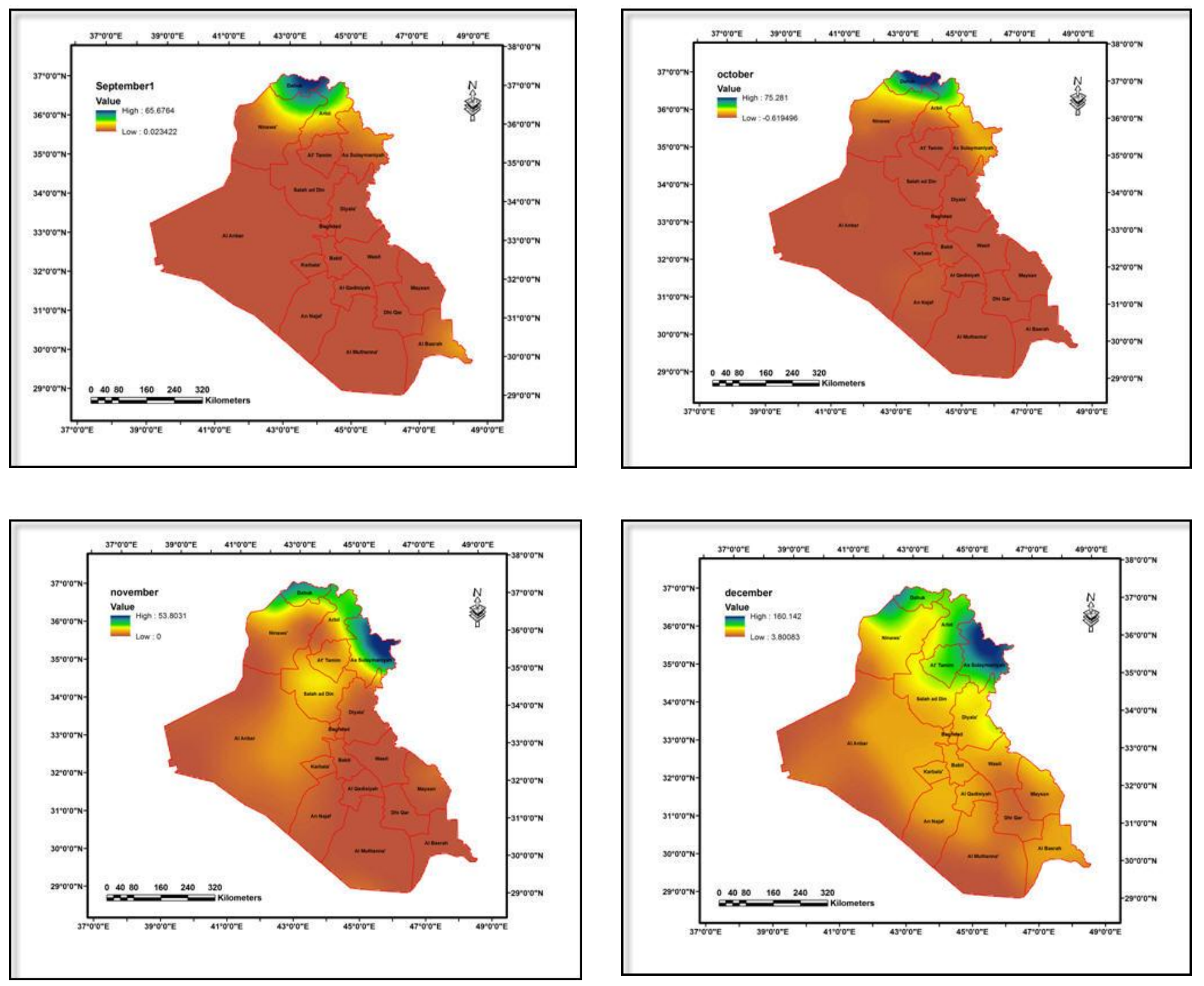

Fig. 6: Monthly Precipitation (September to December). 
صباح حسين علي
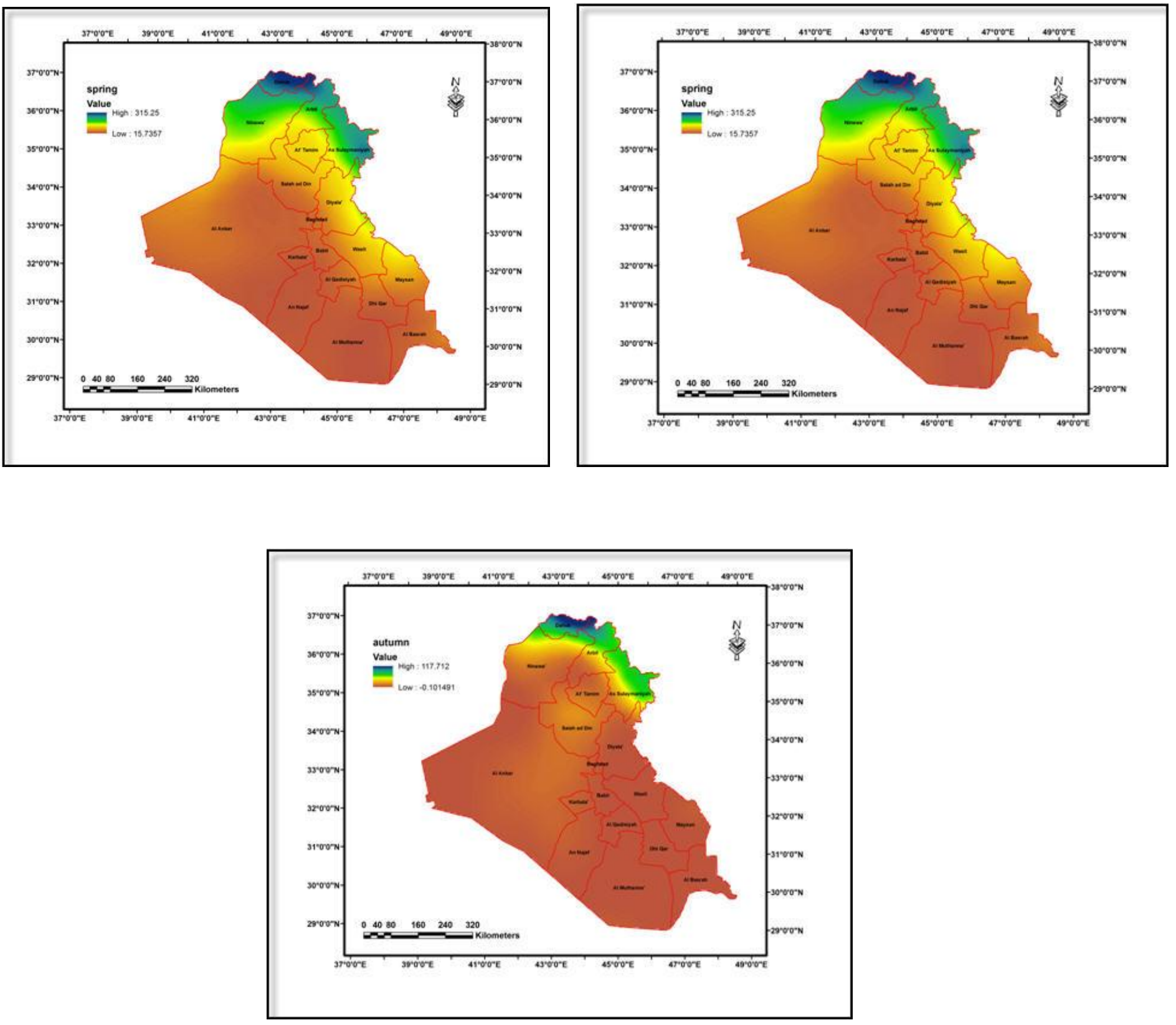

Fig. 7: Seasonal Precipitation (Winter, Spring and Autumn).

Figures (8 and 9) illustrate the monthly and seasonal variation of the precipitation in 2016 respectively. It is noticed that the maximum value of precipitation occurs in December, January, March, April and February see table (1), while maximum seasonal precipitation occurs in winter, spring and autumn with nearly no precipitation falling in summer. 


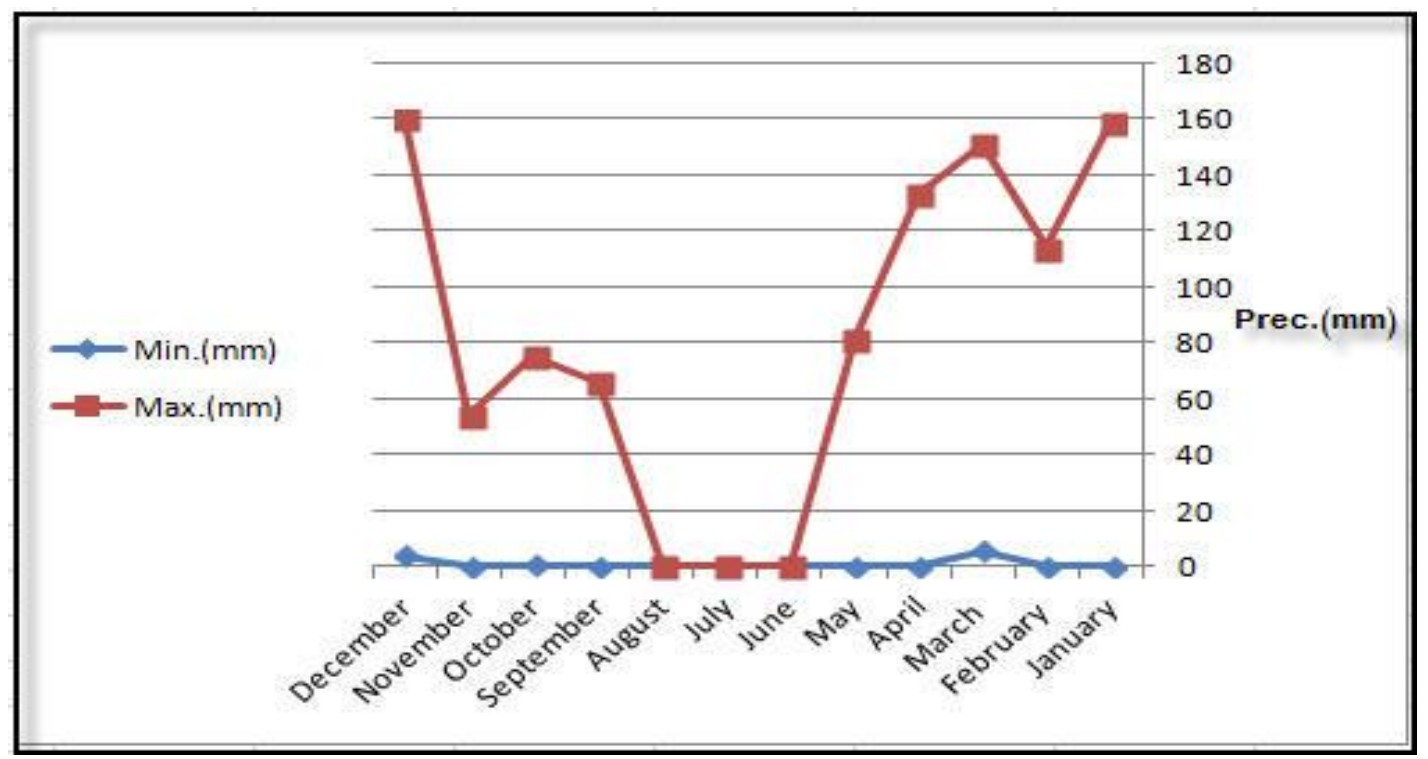

Fig. 8: Monthly Precipitation from January to December 2016.

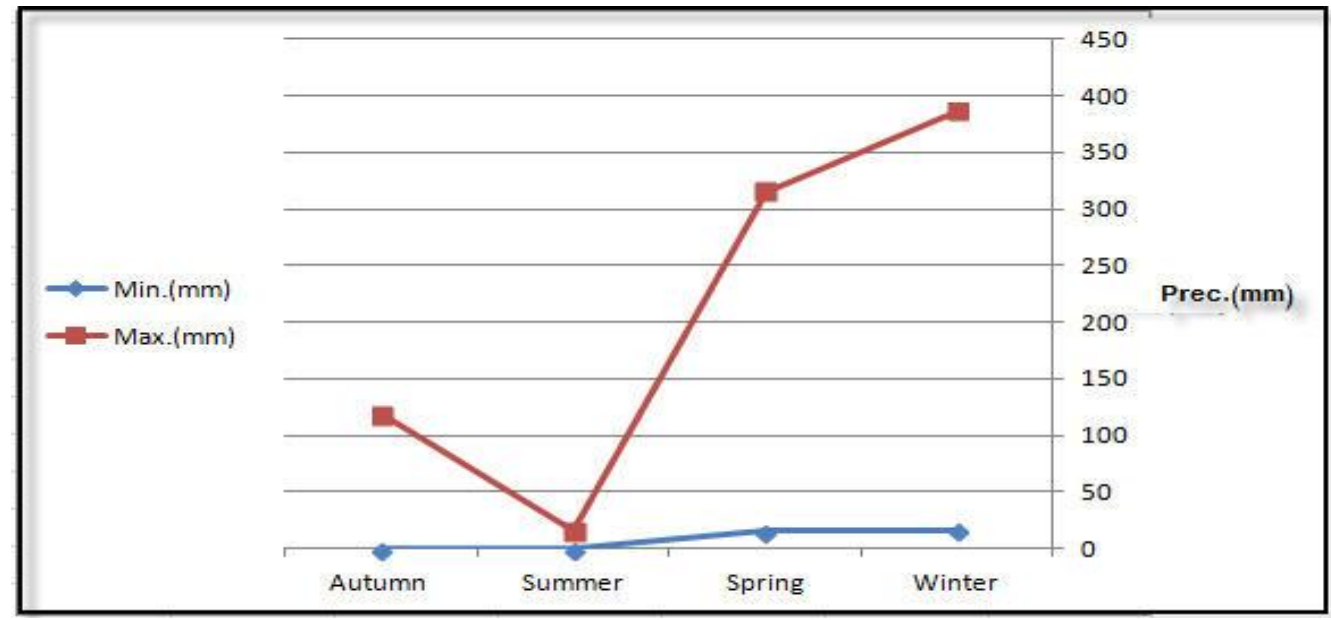

Fig. 9: Seasonal Precipitation in year 2016.

\section{CONCLUSION}

This study focused on the processing and mapping of the precipitation datasets that downloaded from the well-known climatic website. ArcGIS10.3/ Kriging interpolation method is applied for extracting the final monthly and seasonal precipitation surface map. It is concluded that there is a general similarities in the precipitation features of Iraq between the downloaded dataset from the GPCC VISUALIZER web site and those obtained from the meteorological stations. During November through April, the country received maximum annual precipitation, with highest precipitation rates occurring during December through April. In addition, it is concluded that, the spatial resolution of the monthly and seasonal precipitation maps produced by the Kriging interpolation method for downloaded data is more than those data depending on a limited number of meteorological stations. 


\section{REFERENCES}

Ali, S.M., Mahdi, A.S., Hussan, Q.M., Al-Azawi, F.W., 2013. Fluctuating Rainfall as one of the Important Cause for Desertification in Iraq. Journal of Environment and Earth Science, Vol.3, No. 2, pp. 25 - 33.

Becker, A., 2011. The Global Precipitation Climatology Centre (GPCC) to Support the GCW on ECV Precipitation: Caps and Constrains. 1st GCW Implementation Meeting, 21 - 24 November 2011, Geneva, pp. 1 - 40.

Daly, C., Taylor, G. H., Gibson, W.P., Parzybok, T.W., Johnson, G.L., Pasteris, P.A., 2000. HIGH-QUALITY SPATIAL CLIMATE DATA SETS FOR THE UNITED STATES AND BEYOND. Transactions of the ASAE, Vol.43, No.6, pp. 1957-1962.De Pauw, E., 2008. Climatic and Soil Datasets for the ICARDA Wheat Genetic Resource Collections of the Eurasia Region Explanatory Notes. Technical Note, ICARDA GIS Unit.

http://www.ncdc.noaa.gov/cdo-web/, accessed at: 14Feb.2014.

http://lib.stanford.edu/stanford-geospatial-center/GIS-\%2526-Climate, accessed at: 14Feb.2014.

http://www7.ncdc.noaa.gov/CDO/cdoselect.cmd?datasetabbv=GSOD\&countryabbv=

\&georegionabbv $=$, accessed at: 22 Feb.2014.

http://www.fao.org/nr/climpag/pub/EN1102_en.asp, accessed at: 22 Feb.2014.

http://www.worldclim.org/, accessed at: 25 Feb.2014.

https://climatedataguide.ucar.edu/climate-data/gpcc-global-precipitation-climatology-

centre, accessed at:1 March2014.

http://kunden.dwd.de/GPCC/Visualizer, accessed at:1 March2014.

Isaaks, H., Srivastava, R., 1989. Applied Geostatistics. Oxford University Press, New York, Oxford.

Al-Kinani, M. N., 2014. Rainfall in early May of 2013 in Iraq (Quantitative and Synoptic Study). Lark of Philosophy, linguistics and Social Sciences. Vol. 6, No. 15 , pp. 365 - 388.

Rajab, J. M., 2012. Analysis of Troposphere Carbon Dioxide in Iraq from Atmosphere Infrared Sounder (AIRS) Data: 2010-2011. Journal of Babylon University/ Pure and Applied Sciences. No.1, Vol. 22. pp. 524 - 531.

Sissakian, V. K., Abdul Ahad, A. D., Al- Ansari, N., Kuntsson, S., 2016. Tourism in North and Northeastern Parts of Iraq. Journal of Earth Sciences and Geotechnical Engineering. Vol. 6, No. 3, pp. 90 - 107.

Al- Timimi, Y.K., Al-Jiboori, M. H., 2013. Assessment of Spatial and Temporal Drought in Iraq During the Period 1980 - 2010. International J. Energy and Environment, Vol.4, Issue.2, pp. 291 - 302.

Wei, W., Li, F., Maofen, L., Hongbin, L., Yaoqin, L., 2012. Sensitivity Analysis of Crop Growth Models to Multi-Temporal Scale Solar Radiation. Transactions of the CSAE, Vol. 28, No. 3, pp.123 - 128. 